\title{
Detection of Campylobacter pylori in stomach tissue by DNA in situ hybridisation
}

\author{
F M VAN DEN BERG,* H ZIJLMANS, * WIES LANGENBERG, $\dagger$ E RAUWS, $\ddagger$ \\ MARGUERITE SCHIPPER* *Department of Pathology, †Department of Bacteriology, and \\ $\ddagger$ Department of Gastroenterology, AMC, University of Amsterdam, Amsterdam, The Netherlands
}

SUMMARY A non-radioactive DNA in situ hybridisation(DISH) protocol was developed. It requires the use of biotinylated Campylobacter pylori DNA as the probe to detect $C$ pylori DNA in routinely embedded stomach biopsy specimens. In sequential tissue samples from a 58 year old woman with recurrent chronic active gastritis the $C$ pylori probe hybridised with bacteria whenever they were histologically visible. When no bacteria were visible histologically, hybridisation was negative with one exception. In a single biopsy specimen without visible $C$ pylori, hybridisation occurred with the surface of the antrum epithelium, while control hybridisation with a heterologous probe remained negative. From a parallel biopsy specimen taken at the same time the $C$ pylori culture was positive.

It is concluded that DISH, although more laborious than routine staining techniques, may be more sensitive in that it detects bacteria very easily, even when sections are not counterstained or when they are present in low numbers, and that bacteria which do hybridise are unequivocally identified as $C$ pylori and not Campylobacter-like organisms.

As early as 1893 a curved bacterium had been observed in the stomach of man, ${ }^{1}$ but it was only in 1983 that the presence of this bacterium was linked to the development of gastritis. ${ }^{23}$ The bacterium morphologically resembling Campylobacter species was called Campylobacter pyloridis and later renamed $C$ pylori. Although the bacterium still carries this name, it is suspected of belonging to another or novel genus. ${ }^{45}$

It is now well established that $C$ pylori is the major aetiological agent of chronic active gastritis. ${ }^{6-8}$ Whether the presence of $C$ pylori after treatment for gastric ulcers confers an increased risk for ulcer recurrence remains controversial. ${ }^{47}$

C pylori isolates seem to be extremely variable at the DNA level; each isolate has its own characteristic restriction endonuclease digestion pattern. ${ }^{9}$ By using restriction endonuclease digestion of purified $C$ pylori DNA, it has been demonstrated that patients who were apparently successfully treated for $C$ pylori infection, but who seemed to be reinfected at follow up with $C$ pylori, carried the same $C$ pylori type as before treatment. ${ }^{9}$ These results suggested that $C$ pylori may be resistant to antibiotics and may survive in the stomach undected by routine culture and microscopic techniques.
We developed a non-radioactive DNA in situ hybridisation (DISH) protocol using biotinylated $C$ pylori DNA as probe to detect $C$ pylori DNA in paraffin wax embedded tissue sections of stomach biopsy specimens.

\section{Material and methods}

Antral mucosal biopsy specimens were collected endoscopically at regular intervals from 1984 to 1988 from a 58 year old woman with chronic relapsing active gastritis and focal intestinal metaplasia. The patient originally presented with a $C$ pylori associated gastritis. In an attempt to eradicate $C$ pylori she was initially treated with colloidal bismuth subcitrate for two months without success. After she developed a benign gastric ulcer the patient was treated with ranitidine and simultaneously with a five day course of furazolidone with short term success. After a relapse she was treated successfully with amoxycillin. For the past three years she has been free of detectable $C$ pylori.

At each endoscopy $(n=25)$, two biopsy specimens were placed in $2 \mathrm{ml}$ phosphate buffered saline (PBS) at $4^{\circ} \mathrm{C}$ for $C$ pylori culture and two specimens were fixed in formalin and embedded in paraffin wax blocks for histological examination. For in situ hybridisation (DISH) analysis three histologically $C$ pylori positive 
Table Detection of $C$ pylori in selected antrum biopsy specimens from one patient by DNA in situ hybridisation

\begin{tabular}{|c|c|c|c|c|c|}
\hline \multirow{2}{*}{$\begin{array}{l}\text { Biopsy } \\
\text { No }\end{array}$} & \multirow[b]{2}{*}{ Probe } & \multirow[b]{2}{*}{ Culture } & \multirow[b]{2}{*}{ Histology* } & \multicolumn{2}{|l|}{ DISH } \\
\hline & & & & Bacteria & Surface $†$ \\
\hline $84 a$ & $\begin{array}{l}\text { Cpylori } \\
\text { CMV }\end{array}$ & + & + & + & $\begin{array}{l}+ \\
-\end{array}$ \\
\hline $84 b$ & $\begin{array}{l}\text { C pylori } \\
\text { CMV }\end{array}$ & + & - & - & $\stackrel{+}{-}$ \\
\hline $85 a$ & $\begin{array}{l}\text { Cpylori } \\
\text { CMV }\end{array}$ & ++ & ++ & $\begin{array}{l}+ \\
-\end{array}$ & + \\
\hline $85 b$ & $\begin{array}{l}\text { Cpylori } \\
\text { CMV }\end{array}$ & ++ & + & $\stackrel{+}{-}$ & $\stackrel{+}{-}$ \\
\hline $85 c$ & $\begin{array}{l}\text { Cpylori } \\
\text { CMV }\end{array}$ & - & - & - & - \\
\hline $\begin{array}{l}85 d \\
87 a\end{array}$ & $\begin{array}{l}\bar{C} \text { pylori } \\
\text { CMV }\end{array}$ & $\stackrel{+}{-}$ & + & $\begin{array}{l}\text { ND } \\
- \\
-\end{array}$ & $\begin{array}{l}\text { ND } \\
- \\
-\end{array}$ \\
\hline
\end{tabular}

*CLO visible in haematoxylin and eosin staining of tissue section, † Staining of the surface of the antrum epithelium.

biopsy specimens designated $84 a, 85 a$, and $85 \mathrm{~b}$ and three histologically negative biopsy specimens designated $84 b, 85 c$, and $87 a$, were selected. One set of biopsy specimens designated $85 \mathrm{~d}$ was reviewed to confirm the relapse of $C$ pylori infection (table) but was not used in the DISH experiments.

Nine different Campylobacter species were used: $C$ jejuni, $C$ coli, $C$ consisus, $C$ fetus fetus, $C$ jejuni doyley (GCLO2), $C$ laridis, C UPTC, $C$ uppsaliensis and $C$ pylori. From the latter species two different strains $(65$ and 67) were used. Cultures of $50 \mathrm{ml}$ were grown under microaerophillic conditions and bacterial DNA was extracted as described previously. ${ }^{9}$ Human DNA was isolated from cultured fetal lung cells and placenta as described previously. ${ }^{10}$

\section{DOT BLOT HYBRIDISATION}

DNA samples at $10 \mu \mathrm{g} / \mathrm{ml}$ in $0.2 \mathrm{M} \mathrm{NaOH}$ were heated to $100^{\circ} \mathrm{C}$ for five minutes, cooled quickly on ice and quenched by addition of an equal volume of $2 \mathrm{M}$ $\mathrm{NH}_{4} \mathrm{Ac}$. Duplicate $5 \mu \mathrm{l}$ aliquots were spotted on to nitrocellulose membranes (Schleicher \& Schüll, BA84) which had been soaked in $3 \times$ SSC (SSC $=0.15 \mathrm{M}$ $\mathrm{NaCl}, 0.015 \mathrm{M} \mathrm{Na}_{3}$ citrate, $\mathrm{pH} \mathrm{7.0)}$ and $1 \mathrm{M} \mathrm{NH}_{4} \mathrm{Ac}$ and air dried. Dot blots were baked for two hours at $80^{\circ} \mathrm{C}$ and hybridised with $0.5 \mu \mathrm{g}$ in vitro ${ }^{32} \mathrm{P}$ labelled Campylobacter DNA, essentially as described previously. ${ }^{10}$ After hybridisation overnight, duplicate filters were washed at two different stringencies $\left(1 \times\right.$ SSC, $0.5 \%$ sodium dodecyl sulphate, $65^{\circ} \mathrm{C}$, and $0.1 \times \mathrm{SSC}, 0.5 \%$ sodium dodecyl sulphate, $65^{\circ} \mathrm{C}$ ) and autoradiographed with Kodak X-AR2 film for 18 hours.

\section{DNA IN SITU HYBRIDISATION}

Unless otherwise stated, all steps were performed at room temperature. Paraffin wax sections $(5 \mu \mathrm{m})$ were mounted on slides coated with gelatin-chrome alum,
Van den Berg, Zijlmans, Langenberg, Rauws, Schipper

baked at $60^{\circ} \mathrm{C}$ for $16-20$ hours, and stored at $37^{\circ} \mathrm{C}$ until required. To prevent non-specific probe binding and facilitate probe penetration the following pretreatment steps were performed: after deparaffinisation sections were treated with xylometazolin-hydrochlorid (Multipharma) for 30 minutes. After rinsing in PBS and dehydration in graded ethanol, sections were incubated in $50 \mathrm{mM}$ glucose, $25 \mathrm{mM}$ TRIS- $\mathrm{HCl}, \mathrm{pH}$ $7.5,10 \mathrm{mM}$ EDTA containing $30 \mathrm{mg} / \mathrm{ml}$ freshly dissolved Lysozym (Sigma) for 10 minutes, rinsed in PBS, and incubated with $50 \mu \mathrm{g} / \mathrm{ml}$ proteinase $\mathrm{K}$ (Boehringer) in $20 \mathrm{mM}$ TRIS-HCl, $\mathrm{pH} \mathrm{7.5,2} \mathrm{mM} \mathrm{CaCl}_{2}$ for 30 minutes at $37^{\circ} \mathrm{C}$. Sections were rinsed in PBS and incubated in PBS containing $3 \% \mathrm{H}_{2} \mathrm{O}_{2}$ for 30 minutes.

After dehydration and drying, sections were prehybridised in HybMix $(=2 \times \mathrm{SSC}$, pH $7 \cdot 0,50 \%$ formamid, $250 \mu \mathrm{g} / \mathrm{ml}$ single stranded carrier DNA, $10 \times$ Denhardt's solution, $10 \%$ dextran sulphate, $0.5 \%$ Tween $20,0 \cdot 1 \%$ d-biotin) for one hour at $37^{\circ} \mathrm{C}$ and subsequently rinsed in PBS, $0.5 \%$ Tween 20 , dehydrated and air dried. Biotinylated $C$ pylori DNA probe (10 ng) or human cytomegalovirus (CMV) DNA probe ${ }^{11}$ in $10 \mu \mathrm{l}$ HybMix was applied to the sections which were covered with a glass coverslip. Probe and target DNA were simultaneously denatured by placing the sections on an $80^{\circ} \mathrm{C}$ hotplate for 10 minutes. Hybridisation was performed for 10 hours at $37^{\circ} \mathrm{C}$ in a sealed humidified container.

Coverslips were removed by submerging the sec tions in $0.3 \times$ SSC, $50 \%$ formamid, $0.5 \%$ Tween $20 \%$ and sections were thoroughly rinsed in the same buffer. Hybridised biotin labelled probe sequences were visualised in the sections by sequential incubations in $10 \%$ normal swine serum in PTB (=PBS containing $0.5 \%$ Tween 20 and $1 \%$ bovine serum albumin), $0 \cdot 1 \%$ rabbit anti-biotin (Dako) in PTB for one hour, and $2 \%$ horseradish peroxidase (HRP) conjugated swine anti-rabbit Ig (Dako) in PTB for 30 minutes. HRP activity was developed with $0.5 \mu \mathrm{g} / \mathrm{ml}$ diaminobenzine (DAB), $0.02 \% \mathrm{H}_{\mathrm{i} 2} \mathrm{O}_{2}$ in $50 \mathrm{mM}$ TRIS$\mathrm{HCl}, \mathrm{pH} 7 \cdot 8$, for four to six minutes. DAB precipitate was enhanced using an experimental silver enhancement kit (Janssen Pharmaceutica) resulting in dark brown to black deposits.

\section{Results}

To obtain maximal DISH efficiency" the total $C$ pylori genome was used as a DISH probe. To test whether $C$ pylori DNA crosshybridised with human DNA or DNA from other Campylobacter species, dot blot hybridisation analysis was performed as summarised in fig 1 . In vitro ${ }^{32} \mathrm{P}$ labelled total $C$ pylori (65) DNA did not hybridise with other Campylobacter species and only weakly hybridised at low stringency with human DNA; in contrast, it hybridised strongly with 


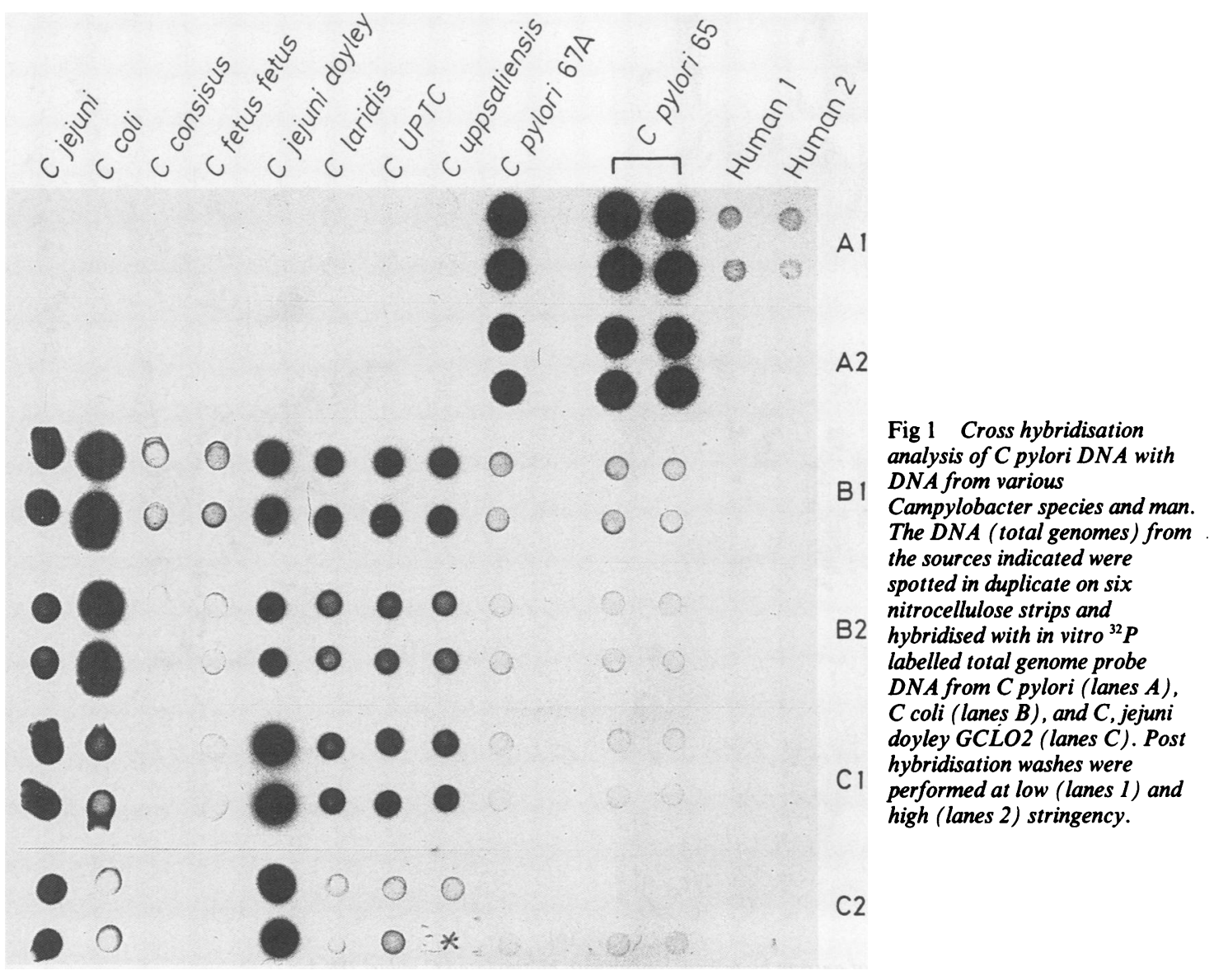

DNA from a different $C$ pylori strain (fig 1; A1, 2). These results confirmed that $C$ pylori is not closely related to most members of the genus Campylobacter. ${ }^{5}$ When $C$ coli or $C$ jejuni doyley (GCLO2) DNA were used as probe (fig $1 ; \mathrm{B} 1,2$ and $\mathrm{Cl}$, 2, respectively) these Campylobacter species cross hybridised with most other species but not with $C$ pylori or human DNA.

For DISH experiments $C$ pylori DNA was biotinylated and applied to paraffin wax embedded tissue sections of a series of selected antrum biopsy specimens from a patient with recurrent $C$ pylori associated gastritis. Initial experiments with routine DISH techniques using streptavidin/polyalkaline phosphatase staining ${ }^{112}$ were only weakly positive in the morphologically visible Campylobacter-like organisms (CLO) in some of the stomach biopsy specimen (data not shown) and showed strong background staining. Therefore, we developed a highly sensitive DISH procedure which entailed extensive proteolytic pre-treatment, background reduction with mucus dissolving pharmaceuticals and free d-biotin, combined with the enhancement of DAB precipitate with metallic silver. The results with this protocol are shown in fig 2 and summarised in the table. Whenever CLO were histologically visible they were strongly stained with the $C$ pylori probe (fig $2 \mathrm{~b}$ ) while cytomegalovirus probe was negative. In these cases focal $C$ pylori specific hybridisation of the epithelial surface in the vicinity of $C$ pylori organisms was often found. In biopsy $84 \mathrm{~b}$ a similar hybridisation of the surface of the epithelium was observed without the visible presence of bacteria (fig 2d); the cytomegalovirus probe did not stain the epithelium surface in this biopsy specimen. From one of the parallel biopsy samples of $84 \mathrm{~b}$ the $C$ pylori culture was positive (table).

\section{Discussion}

Fig 1 shows that $C$ pylori probably does not belong to 


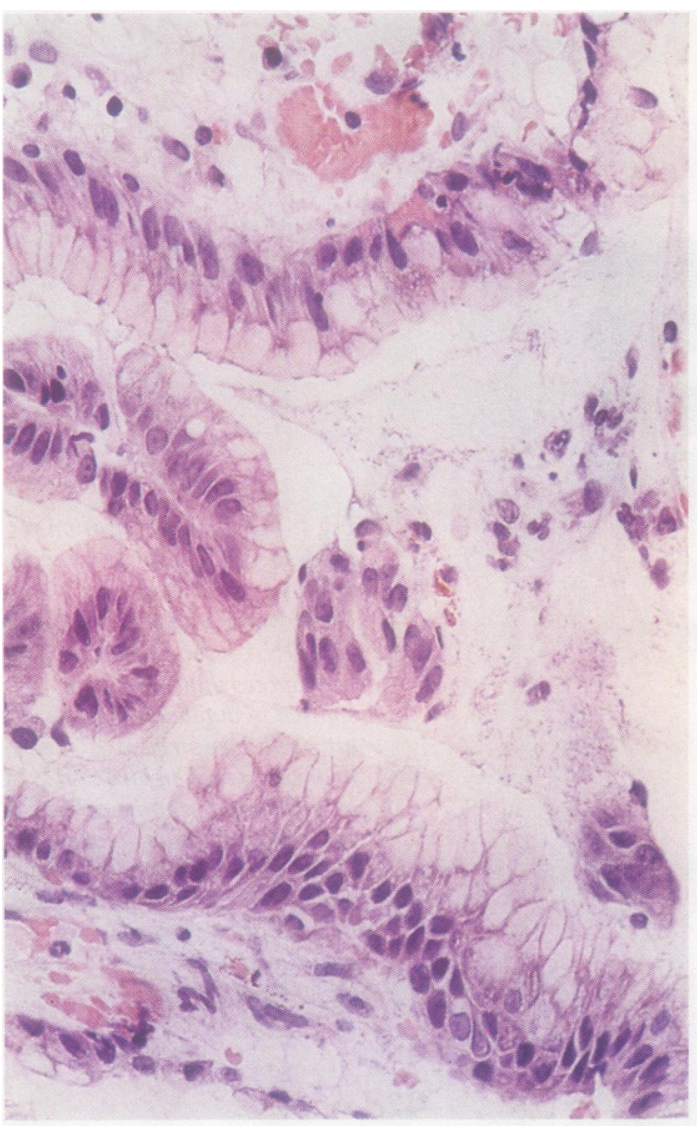

(a)

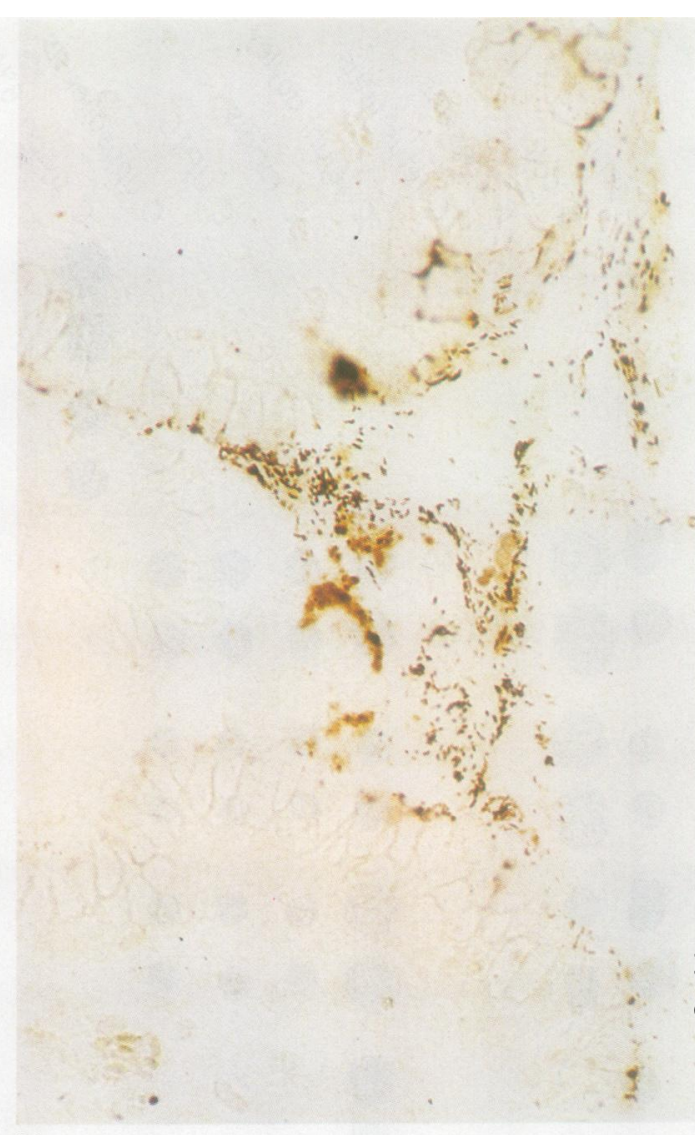

(b)

Fig 2 DNA in situ hybridisation of antrum biopsy specimens with biotinylated C pylori DNA.

Paraffin wax sections of antrum biopsy specimens were mounted on coated slides and processed for DNA in situ hybridisation. (a) Biopsy 85a haematoxylin and eosin stain; (b) biopsy 85a DISH with C pylori probe and HRP/DAB-silver staining.

the genus Campylobacter as has been suggested by others ${ }^{45}$ because there is no cross-hybridisation between the total genome DNA of the different species. The results in lanes $B$ and $C$ could suggest, however, that $C$ pylori may be related to $C$ consisus and $C$ fetus fetus because these species hybridise to the same extent to $C$ coli and $C$ jejuni doyley probe as does $C$ pylori. The results in lanes $A$ refute this conclusion, however, as $C$ consisus and $C$ fetus fetus do not (cross) hybridise with $C$ pylori even under low stringency conditions (lane A1).

As shown in fig 2 DISH is quite a sensitive technique to detect $C$ pylori organisms in antrum biopsy specimens. Although DISH is more laborious than haematoxylin and eosin, silver, or Giemsa staining, it may be more sensitive and has important advantages over these routine staining methods: (i) bacteria are very easily detected, especially when sections are not counterstained, even when they are present in low numbers; (ii) bacteria that do hybridise are unequivocally identified as $C$ pylori and not merely as CLO; (iii) in biopsy 84b, of which a parallel specimen from the same region of the antrum gave positive culture results, DISH detected $C$ pylori DNA hybridisation in the epithelial surface, while histological examination did not show $C$ pylori at this location (fig 2d, table).

Regarding the issue of relapsing $C$ pylori infection we must conclude that in our patient $C$ pylori does not persist in clinically important numbers in undetectable form in the antrum mucosa after apparent eradication. An intact genome must be conserved to enable revival of infectious bacteria and such bacterial DNA molecules would theoretically be detected by DISH. In our patient $C$ pylori DISH of biopsy $85 \mathrm{c}$ was negative (as were the histology and culture results) while a 


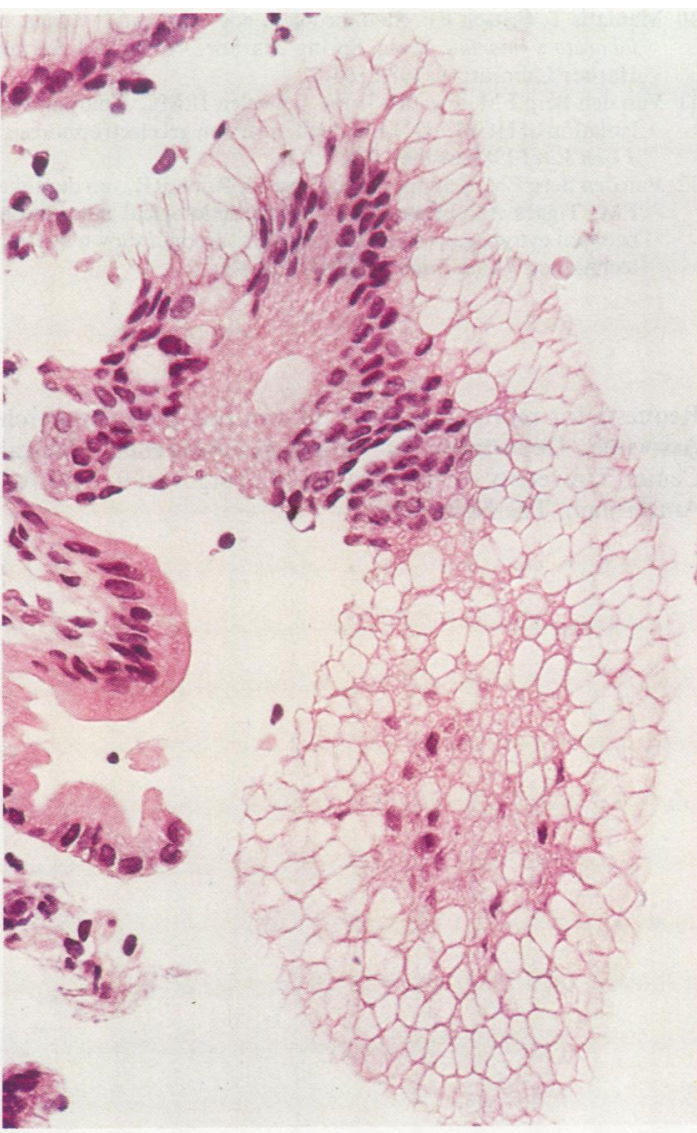

(c) (d)

Fig 2 (c) Biopsy $84 b$ haematoxylin and eosin stain; (d) biopsy $84 b$ DISH with C pylori probe and HRP/DAB-silver staining.

relapsing infection with the same $C$ pylori strain was seen one month later (table, biopsy $85 \mathrm{~d}$ ). This result presents us with a problem because the fact remains that patients with relapsing $C$ pylori infection are generally "reinfected" with their "own" $C$ pylori strain.' An explanation for this phenomenon may be that some $C$ pylori organisms survive eradication and persist in a different part of the stomach (such as the fundus) from which biopsy specimens are not normally taken.

The DISH result with biopsy $84 \mathrm{~b}$ (table), in which $C$ pylori probe hybridised to the periepithelial mucous layer of the antrum (fig $2 \mathrm{~d}$ ), could suggest the presence of latent bacteria at this site in a morphologically obscure form. In our opinion it is more likely that the probe detects debris, including DNA fragments, of recently eradicated bacilli. Interestingly, the epithelial surface staining was not present in other parts of the same biopsy specimen with intestinal metaplasia. Obviously these observations need to be substantiated with additional experiments using tissue samples from several different patients.

We thank Dr J Oudbier for assistance with the purification of Campylobacter DNA and Mrs A Widjojokusumo for culturing the different Campylobacter species.

\section{References}

1 Doenges JL. Spirochetes in the gastric glands of macacus rhesus and man without related disease. Archives of Pathology 1939;18:469-77.

2 Warren JR. Unidentified curved bacilli on gastric epithelium in active chronic gastritis. Lancet 1983;i:1273-5.

3 Marshall BJ, Warren JR. Unidentified curved bacilli in the stomach of patients with gastritis and peptic ulceration. Lancet 1984;i:1311-15. 
4 Marshall BJ. Campylobacter pyloridis and gastritis. J Infect Dis 1986;153:650-7.

5 Romaniuk PJ, Zoltowska B, Trust TJ, et al. Campylobacter pylori, the spiral bacterium associated with human gastritis, is not a true Campylobacter sp. J Bacteriol 1987:169:2137-41.

6 Jones DM, Lessells AM, Eldridge J. Campylobacter like organisms on the gastric mucosa: culture, histological, and serological studies. J Clin Pathol 1984;37:1002-6.

7 Loffeld RJLF, Loffeld BCAJ, Arends JW, Flendrig JA, van Spreeuwel JP. Retrospective study of Campylobacter-like organisms in patients undergoing partial gastrectomy. J Clin Pathol 1988;41:1313-15.

8 Musgrove C, Bolton FJ, Krypczyk AM, et al. Campylobacter pylori: clinical, histological and serological studies. J Clin Pathol 1988;41:1316-21.

9 Langenberg W, Rauws AJ, Widjojokusumo A, Tytgat GNJ, Zanen HC. Identification of campylobacter pyloridis isolates by restriction endonuclease DNA analysis. J Clin Microbiol 1986;24:414-17.
10 Maniatis T, Fritsch EF, Shambrook J, eds. Molecular cloning, a laboratory manual. Cold Spring Harbor, NY: Cold Spring Harbor Laboratory, 1982:164-7.

11 Van den Berg FM, Jiwa M, Rook J, Geelen JLMC. Analysis and Isolation of HCMV DNA by field inversion gel electrophoresis. J Gen Virol 1988;69:699-704.

12 Van den Berg FM, Schipper MEI, Jiwa M, Rook RR, van de Rijke FM, Tigges AJ. Implausibiity of an aetiological association between cytomegalovirus and Kaposi's sarcoma shown by four techniques. J Clin Pathol 1989;42:128-41.

Requests for reprints to: Dr F M van den Berg, Research Associate, Department of Pathology, Academic Medical Center, University of Amsterdam, Meibergdreef 9, $1105 \mathrm{AZ}$ Amsterdam, The Netherlands. 